Original Article

\title{
The first record of Bergamina lineolata (Chydoridae; Aloninae) from Colombia
}

\author{
O primeiro registro de Bergamina lineolata (Chydoridae; Aloninae) na Colômbia \\ J. M. Fuentes-Reinés ${ }^{a *}$ (i), P. Eslava-Eljaiek ${ }^{\mathrm{a}}$ (i) and L. M. A. Elmoor-Loureirob (i) \\ aUniversidad del Magdalena, Grupo de Investigación en Biodiversidad y Ecología Aplicada, Santa Marta, Colombia \\ bUniversidade Federal de Jataí - UFJ, Unidade Acadêmica Especial de Ciências Biológicas, Laboratório de Taxonomia Animal, Jataí, GO, Brasil
}

\begin{abstract}
The Neotropical freshwater cladoceran Bergamina lineolata (Sars, 1901) was found in a small temporal pond in the Magdalena department. Hitherto, it has been reported in Brazil and El Salvador. It was originally described as Alonella lineolata by Sars, 1901 from Brazil and then placed to the genus Bergamina by Elmoor-Loureiro et al. (2013). This is the first record of this species in Colombia. B. lineolata can be identified by a unique combination of characters including: 1 ) a remarkably large and oblong postabdomen, with three denticles on distal corner; 2 ) basal spine of the claw very short, length less than the half claw diameter at base; 3) IDL with two setae shorter than ODL seta, armed with fine setules unilaterally in terminal half; 4) endite 1 of trunk limb I with a long smooth seta between endites 1 and 2 .
\end{abstract}

Keywords: aquatic vegetation, temporary pond, neotropic, Cladocera, taxonomy.

\begin{abstract}
Resumo
O cladócero neotropical de água doce Bergamina lineolata (Sars, 1901) foi encontrado em uma pequena lagoa temporária no departamento de Magdalena, na Colômbia. Até o momento, havia sido relatado no Brasil e em El Salvador. Foi originalmente descrito como Alonella lineolata por Sars, 1901 no Brasil, e, em seguida, colocado no gênero Bergamina por Elmoor-Loureiro et al. (2013). Esse é o primeiro registro dessa espécie na Colômbia. B. lineolata pode ser identificada por uma combinação única de caracteres, incluindo: 1) um pós-abdômen notavelmente grande e oblongo, com três dentículos no ângulo distal; 2) espinho basal da garra muito curto, comprimento menor que o diâmetro da metade da garra na base; 3) IDL com duas cerdas mais curtas que cerdas ODL, armadas com sétulas finas unilateralmente na metade terminal; e 4) endito 1 do toracópodo I com uma longa cerda lisa entre os enditos 1 e 2.
\end{abstract}

Palavras-chave: vegetação aquática, lagoa temporária, neotrópico, Cladocera, taxonomia.

\section{Introduction}

The Superorder Cladocera is one of the major zooplankton groups in many freshwater bodies (Jeong et al., 2015) and constitutes a vital component in aquatic food web worldwide by transferring energy from the lower (phytoplankton, bacteria, fungi) to higher trophic levels (Choedchim et al., 2017). Members of this group can inhabit in the deep zone of large lakes, ground waters, caves, between leafs of bromeliad plants, in small drops of water, on the mosses of cloud tropical forests (Sinev, 2002). This group comprises more than 700 species (Jeong et al., 2015) and they are dominant in littoral zone with macrophytes (Maia-Barbosa et al., 2008), nevertheless some species are not very frequent in sampling and has not been reported very often (e.g., Bryospilus repens Frey, 1980, Anthalona milleri (Kiser, 1948), A. obtusa Van Damme, Sinev \& Dumont, 2011, A. spinifera Tiang-nga, Sinev \& Sanoamuang, 2016) and they can be considered rare species (Kotov et al., 2013; Sousa et al., 2014; Sinev, 2016). Bergamina lineolata is also considered a rare species (Elmoor-Loureiro et al., 2013).

Bergamina lineolata is considered the sole species of the genus, and it has an exclusively Neotropical distribution. It was originally described as Alonella lineolata by Sars, 1901 from a single female found in aquaria prepared with dried mud from São Paulo, Brazil. Nevertheless, it was placed as incertae sedis by Smirnov (1996). Later on, Elmoor-Loureiro et al. (2013) redescribed Alonella lineolata and created the genus Bergamina.

The aim of this contribution is to document the first record of B. lineolata for Colombia, which expands its known distributional range, and also to provide comparative morphological data and illustrations of the Colombian specimens. 


\section{Material and Methods}

Biological samples were taken from a small temporary pond located in Pivijay, Magdalena-Colombia $\left(10^{\circ} 27^{\prime} 10.93^{\prime \prime} \mathrm{N} ; 7^{\circ} 23^{\prime} 33.16^{\prime \prime} \mathrm{W}\right)$. This small (surface area of $2820 \mathrm{~m}^{2}$ ) temporary pond, is a shallow water body (depth $3 \mathrm{~m}$ ). Qualitative surveys were performed in November 2020. Environmental parameters were measured with a WTW 3111 conductivity meter gear. Water samples were obtained using a bucket of $65 \mathrm{~L}$, filtered with a $55 \mu \mathrm{m}$ mesh size plankton net to obtain concentrates of $500 \mathrm{~mL}$ that were fixed in $96 \%$ ethanol. In the laboratory, samples were stained with Bengal rose and concentrated to 50 $\mathrm{mL}$ volume. A Bogorov chamber was used to sort and count cladocerans, with the aid of a stereomicroscope. Cladocerans were taxonomically examined in toto under a compound optical microscope in a drop of glycerolformaldehyde mixture. Specimens were measured in lateral position, from the anterior end of the head to the posterior margin of carapace and then they were dissected to examine the taxonomically relevant appendages, which were mounted in semi-permanent slides. The appendages with taxonomic relevance were photographed using a Kodak Easy Share C140 digital camera adapted to a compound microscope at $1000 \times$ magnification.

The identification of this species, initially, followed the illustrations and descriptions by Sars (1901) and ElmoorLoureiro et al. (2013). For more robust comparison, some available material from type locality (a farm pond from Pradópolis, Brazil, $21^{\circ} 20.624^{\prime}$ S; $48^{\circ} 07.125^{\prime} \mathrm{W}$ ) has been also analyzed (slides EL01570 and EL02307), as well images previously taken of the neotype (MZUSP 15547).

The dissected materials (slide) were deposited at the Centro de Colecciones Biológicas held at the Universidad del Magdalena, Colombia (CBUMAG: MEI: 0828-1-CBUMAG: MEI: 0828-6) where they are available for consultation and/ or further examination.

\section{Results}

\subsection{Taxonomy}

Order Anomopoda Sars, 1865

Family Chydoridae Dybowski \& Grochowski, 1894 emend. Frey, 1967

Subfamily Aloninae Dybowski and Grochowski, 1894 emend. Frey, 1967

Tribe Alonini Dybowski \& Grochowski, 1894 emend. Kotov, 2000

\section{Genus Bergamina}

Bergamina lineolata (Sars, 1901)

Material examined: 2 adult females specimens were collected by one of us (JMF-R) from an ephemeral pond located in Magdalena, Colombia (10²7'12.20" N; 74'23'33.2” W) in November 2020 (Figures 1-12).

\subsection{Morphology}

General shape subquadrate (Figures 1,2 ), body length of the Colombian female specimens $=294-322 \mu \mathrm{m}(n=2$, average length $=308 \mu \mathrm{m})$. Maximum height in posterior half, height/length = about 0.7-0.72 (0.66-0.68 in Brazilian specimens, Figure 13). Rostrum short and relatively blunt, ocellus smaller than eye (Figure 1). With three connected head pore, the central major pore is the smallest (Figure 3 ), PP/IP about 0.36 (0.26-0.30 in Brazilian specimens) (Figure 14). Labral keel in lateral view quite quadrangular (instead of triangular, as in Brazilian specimens) without ornamentation (Figure 4), antenna I almost reaching tip of rostrum (Figure 1B). Antenna II with setal formula 1-13/0-0-3 (Figure 5), spine on the first exopodal segment of antenna II reaching the middle of the second segment (Figure 6). Mandibles are elongated; their distal ends (mandibular surfaces) bear small ridges.

Postabdomen large and oblong (Figure 7). Preanal margin somewhat longer than the anus. Preanal angle evident, but postanal not well defined. Postanal dorsal margin with about 9 denticles, the distal ones are the longest (Figure 8), with three distal denticles larger than the others. Postabdominal claw almost as long as pre-anal margin, slightly and evenly curved. Basal spine very short (Figure 9), but longer than Brazilian specimens (Figure 15). Outer distal lobe (ODL) and inner distal lobe (IDL) of limb I with one and two setae respectively (Figure 11). The IDL setae with fine setules unilaterally in terminal half and both of them shorter than ODL seta (Figure 11). The endite 1 of trunk limb I bears a long seta (Figure 10). Limb II with exopodite with elongate lobe and without seta, inner-distal limb portion with scrapers 1-4 (numeration according to Kotov, 1999) and 6-8 decreasing in size, scraper 5 longer than 4 (Figure 12); distal armature of gnathobase with three elements, filter plate with seven setae.

\subsection{Remarks}

The specimens were found among aquatic vegetation. At sampling time, the pond water temperature was $28^{\circ} \mathrm{C}, \mathrm{pH}$ value was 6.3 , the conductivity $95 \mu \mathrm{S} \cdot \mathrm{cm}-1$, and dissolved oxygen $0.72 \mathrm{mg} / \mathrm{mL}$.

\section{Discussion}

The studied specimens (two adult females), apart of some details, agreed with the descriptions of Sars (1901) and Elmoor-Loureiro et al. (2013). Bergamina lineolata can be easily recognized by a unique combination of characters including: 1) flattened and quadrangular shape; 2) a remarkably large and oblong postabdomen; 3 ) basal spine of the claw very short, length less than the half claw diameter at base; 4) IDL with two setae shorter than ODL seta, armed with fine setules unilaterally in terminal half; 5) endite 1 of trunk limb I with a long smooth seta between endites 1 and 2 . These distinctive traits are also characteristic of the specimen from Colombia.

Some morphological traits of the Colombian specimens show differences from Brazilian specimens (ElmoorLoureiro et al., 2013; present study, Figures 13-15), such as higher height/length ratio, the quadrangular labral plate, longer basal spine on postabdominal claw, and higher PP/IP ratio. Nevertheless, for both populations, only few specimens have been studied, so that is premature to suggest they belong to separate species. Instead, it is 

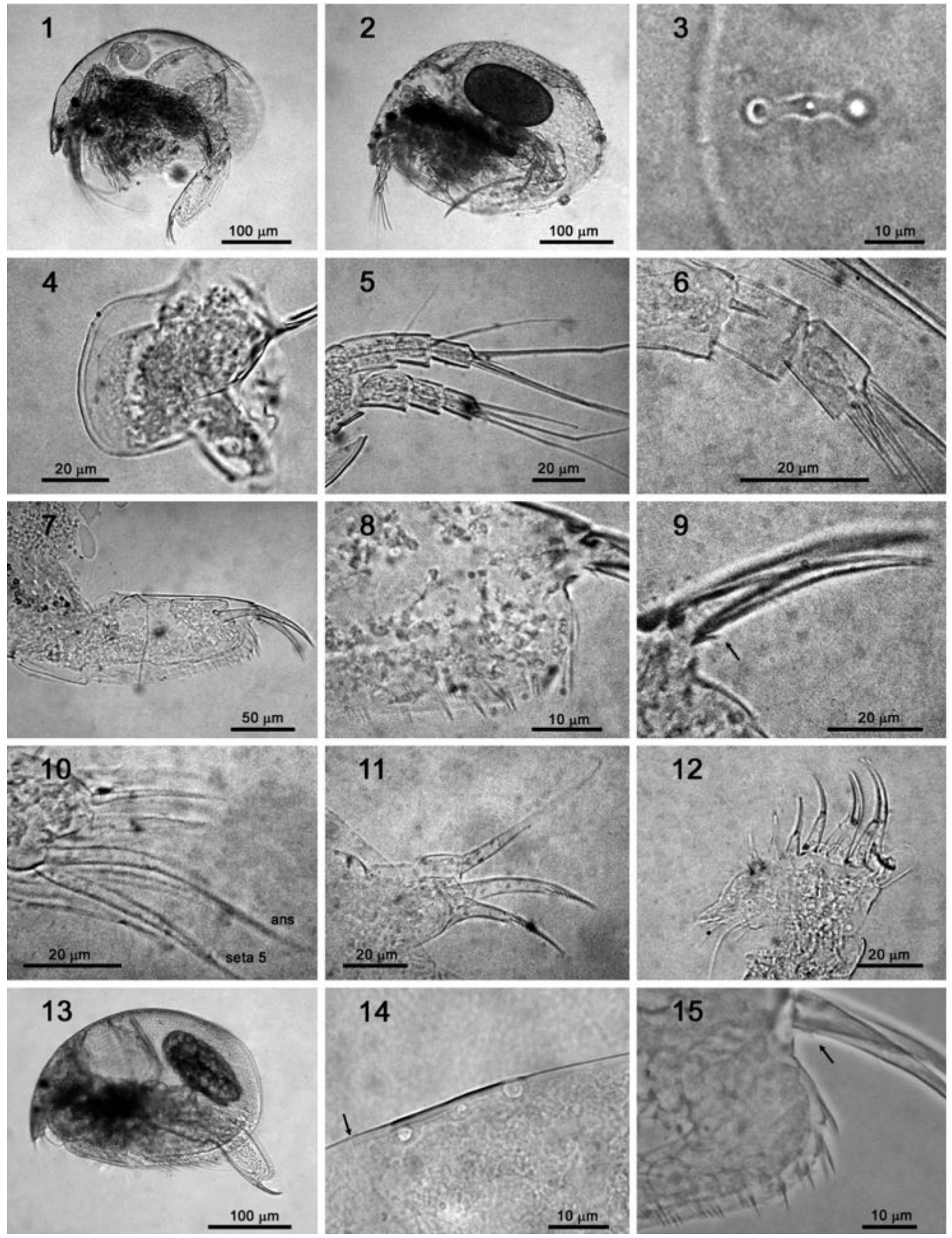

Figures 1-15. Bergamina lineolata (Sars, 1901). 1-12. Specimens from a temporary pond in Pivijay, Magdalena-Colombia (1-2. Parthenogenetic female, habitus; 3. Head pores; 4. Labrum; 5. Antenna; 6. Antennal exopodite; 7-8. Postabdomen; 9. Postabdominal claw, arrow indicates the basal spine; 10. First trunk limb, endites 1-3; 11. First trunk limb, ODL and IDL; 12. Second trunk limb). $13-15$. Specimens from type locality, Brazil (13. Parthenogenetic female, neotype, habitus; 14. Head pores, arrow indicates the posterior margin of head shield; 15. Distal part of the postabdomen, arrow indicates the basal spine). 
recommended to extend the sampling in both countries, allowing a more robust comparison.

In the surveyed area, $B$. lineolata was found in the littoral zone, related to the aquatic vegetation. This species has been also found associated with the aquatic macrophytes and shallow ponds (Maia-Barbosa et al., 2008; CastilhoNoll et al., 2010, 2012; Elmoor-Loureiro et al., 2013), supporting the idea that $B$. lineolata can be classified according to Wetzel (2001) as a species associated with macrophytes. Members of the family Chydoridae are truly scraper feeder on periphyton (Fryer, 1968; Elmoor-Loureiro, 2007), but further ecological studies is needed.

Distribution. B. lineolata has been previously reported in Brazil (Sars, 1901; Maia-Barbosa et al., 2008; CastilhoNoll et al., 2010; Rocha et al., 2011; Santos-Wisniewski et al., 2011) and El Salvador (Collado et al., 1984); this is the first record for Colombia. The presence of $B$. lineolata in adjacent areas seems very likely, so a wider distribution in South America might be expected. The diversity and distribution of this genus in the Neotropical region deserve further research.

\section{Acknowledgements}

We are especially grateful to MINCIENCIAS for financial support through the Magdalena University, Research vicerrectory.

\section{References}

CASTILHO-NOLL, M.S.M., CAMARA, C.F., ABRA, J. and STEPHAN, L.R., 2012. Fauna de invertebrados planctônicos e fitófilos em ambientes lênticos associados a fragmentos florestais remanescentes da região noroeste do estado de São Paulo. In: O. NECCHI JÚNIOR, ed. Fauna e flora de fragmentos florestais remanescentes da região noroeste do estado de São Paulo. Ribeirão Preto: Holos Editora, pp. 137-153.

CASTILHO-NOLL, M.S.M., CÂMARA, C.F., CHICONE, M.F. and SHIBATA, E.H., 2010. Pelagic and littoral cladocerans (Crustacea, Anomopoda and Ctenopoda) from reservoirs of the Northwest of São Paulo State, Brazil. Biota Neotropica, vol. 10, no. 1, pp. 21-30. http://dx.doi.org/10.1590/S1676-06032010000100001.

CHOEDCHIM, W., VAN DAMME, K. and MAIPHAE, S., 2017. Spatial and temporal variation of Cladocera in a tropical shallow lake. Annales de Limnologie-International Journal of Limnology, vol. 53, pp. 233-252. http://dx.doi.org/10.1051/limn/2017006.

COLLADO, C., FERNANDO, C.H. and SEPHTON, D., 1984. The freshwater zooplankton of Central America and the Caribbean. Hydrobiologia, vol. 113, no. 1, pp. 105-119. http://dx.doi. org/10.1007/BF00026597.

ELMOOR-LOUREIRO, L.M.A., 2007. Phytophilous cladocerans (Crustacea, Anomopoda and Ctenopoda) from Paranã River Valley, Goiás, Brazil. Revista Brasileira de Zoologia, vol. 24, no. 2, pp. 344-352. https://doi.org/10.1590/S010181752007000200012 .

ELMOOR-LOUREIRO, L.M.A., SANTOS-WISNIEWSKI, M.J. and ROCHA, O., 2013. Redescription of Alonella lineolata Sars, 1901
(Crustacea, Cladocera, Chydoridae) and its translocation to the subfamily Aloninae and to the new genus Bergamina gen. nov. Zootaxa, vol.3630, no. 3, pp.571-581. http://dx.doi.org/10.11646/ zootaxa.3630.3.11. PMid:26131533.

FRYER, G., 1968. Evolution and adaptive radiation in Chydoridae (Crustacea: Cladocera): A study in comparative functional morphology and ecology. Philosophical Transactions of the RoyalSociety of London (B), vol. 254, pp. 221-385.

JEONG, H., KOTOV, A.A., LEE, W., JEONG, R. and CHEON, S., 2015. Diversity of freshwater Cladoceran species (Crustacea: Branchiopoda) in South Korea. Journal of Ecology and Environment, vol. 38, no. 3, pp. 361-366. http://dx.doi. org/10.5141/ecoenv.2015.037.

KOTOV, A.A., 1999. Redescription of Macrothrix tripectinata Weisig, 1934 (Anomopoda, Branchiopoda), with a discussion of some features rarely used in the systematics of the genus. Hydrobiologia, vol. 403, pp. 63-80.

KOTOV, A.A., VAN DAMME, K., BEKKER, E.I., SIBOUALIPHA, S., SILVABRIANO, M., ORTIZ, A.A., DE LA ROSA, R.G. and SANOAMUANG, L., 2013. Cladocera (Crustacea: Branchiopoda) of Vientiane province and municipality, Laos. Journal of Limnology, vol. 72, no. 2, pp. 81-180. http://dx.doi.org/10.4081/jlimnol.2013.s2.e6.

MAIA-BARBOSA, P.M., PEIXOTO, R.S. and GUIMARÃES, A.S., 2008. Zooplankton in littoral waters of a tropical lake: a revisited biodiversity. Brazilian Journal of Biology = Revista Brasileira de Biologia, vol. 68, no. 4, suppl. 4, pp. 1069-1078. http://dx.doi. org/10.1590/S1519-69842008000500014. PMid:19197477.

ROCHA, O., SANTOS-WISNIEWSKI, M.J. and MATSUMURA-TUNDISI, T., 2011. Checklist de Cladocera de água doce do Estado de São Paulo. Biota Neotropica, vol. 11, no. 1a, suppl. 1, pp. 1-22. http:// dx.doi.org/10.1590/S1676-06032011000500024.

SANTOS-WISNIEWSKI, M.J., MATSUMURA-TUNDISI, T., NEGREIROS, N.F., SILVA, L.C., SANTOS, R.M. and ROCHA, O., 2011. O estado atual do conhecimento da diversidade dos Cladocera (Crustacea, Branchiopoda) nas águas doces do estado de Minas Gerais. Biota Neotropica, vol. 11, no. 3, pp. 1-15. http://dx.doi.org/10.1590/ S1676-06032011000300024.

SARS, G.O., 1901. Contribution to the knowledge of the fresh-water Entomostraca of South America. Part I. Cladocera. Archiv for Mathematik og Naturvidenskab. Christiania, vol. 23, pp. 1-102.

SINEV, A., 2016. Key for identification of Cladocera of the subfamily Aloninae (Anomopoda: Chydoridae) from South-East Asia. Zootaxa, vol. 4200, no. 4, pp. 451-486. http://dx.doi.org/10.11646/ zootaxa.4200.4.1. PMid:27988603.

SINEV, A.Y., 2002. Place of a Central American bromeliad-inhabiting cladoceran Alona bromelicola Smirnov 1998, within the genus (Branchiopoda, Anomopoda,Chydoridae). Arthropoda Selecta, vol. 11, no. 2, pp. 109-116.

SMIRNOV, N.N., 1996. Cladocera: The Chydorinae and Sayciinae (Chydoridae) of the world. Amsterdam: SPB Academic Publishing. $197 \mathrm{p}$.

SOUSA, F.D.R., ELMOOR-LOUREIRO, L.M.A., QUADRA, A. and SENNA, A.R., 2014. First record of Cladocera (Crustacea: Chydoridae) from Parque Nacional do Itatiaia, Southeastern Brazil. Check List, vol. 10, no. 3, pp. 665-668. http://dx.doi.org/10.15560/10.3.665.

WETZEL, R.G., 2001. Limnology lake and river ecosystems. 3th ed. London: Elsevier Academic Press. 